\title{
Short-term Cold Storage of Sperm from Six Neotropical Characiformes Fishes
}

\author{
Simone Marques and Hugo Pereira Godinho* \\ Programa de Pós-Graduação em Zoologia de Vertebrados; Pontifícia Universidade Católica de Minas Gerais; Av. \\ Dom José Gaspar, 500; 30535-610; hgodinho@pucminas.br; smarquess@terra.com.br; Belo Horizonte-MG-Brazil
}

\begin{abstract}
Sperm of the following Neotropical Characiformes fish species were tested for cold storage: Brycon lundii, Piaractus mesopotamicus, Leporinus elongatus, Leporinus friderici, Prochilodus lineatus and Prochilodus marggravii. Each sperm sample was split into two aliquots. The first was placed into a plastic bag with air or oxygen and the second, in a plastic tube with air. The samples were maintained at temperatures between 1.7-4.9 ${ }^{\circ} \mathrm{C}$. The rate of sperm motility was estimated using a $50 \mathrm{mM} \mathrm{NaCl}$ solution as the activating solution. The shortest sperm storage duration ( $7 \mathrm{~h})$ was recorded for $L$. friderici, when the sperm motility rate reached $\sim 30 \%$, whereas the longest duration $(20$ h) was obtained with the sperm of P. lineatus. A fertilisation test using Prochilodus marggravii sperm refrigerated for $8 \mathrm{~h}$ yielded $88-90 \%$ of viable embryos. The refrigerated storage method could be of practical applications, especially in fish reproductive management at hatchery stations.
\end{abstract}

Key words: Cool storage of sperm, sperm motility, semen, Neotropical fishes

\section{INTRODUCTION}

The storage of fish sperm at temperatures above freezing and without the addition of cryoprotectants has long been used as a successful method for refrigerated preservation of sperm (McNiven et al., 1993). This technique is seldom used by Neotropical fish culturists; however, it could be relevant to reproductive management of their fishes, specially given the widespread applications of artificial propagation techniques. Despite its practical importance (Barret, 1951; Billard and Legendre,1982; Kavamoto et al., 1987), this is only the second study to be published in which this storage method is used with Neotropical fishes. In the only publication using one of these species, Ferraz de Lima et al. (1989) reported good results after storing
Piaractus mesopotamicus (Holmberg) sperm for $30 \mathrm{~h}$ in a domestic refrigerator, under oxygen atmosphere. Cold storage is a simple technique that allows sperm to be available at various time intervals, for the fertilisation of eggs produced by hormone-induced females, which ensures greater productivity in the reproductive process. By facilitating the use of sperm from a larger number of males per female, it can help improve the genetic quality of the resulting offspring, in addition to allowing the characteristics of the sperm to be studied (Ciereszko and Dabrowski, 1994). An additional advantage is the ease of transport in appropriate containers (Henderson and Dewar, 1959). Plastic bags (Billard, 1981; Billard and Legendre, 1982; Stoss and Refstie, 1983) and plastic tubes (Chereguini et al., 1997; Wayman et al., 1998) are widely used as storage containers

\footnotetext{
${ }^{*}$ Author for correspondence
} 
to which gases may be added (i.e., oxygen: Billard, 1981; Cieresko and Dabrowski, 1994; Dilauro et al., 1994; Chereguini et al., 1997; Lanhsteiner and Patzner, 1998; Bencic et al., 2000; Jenkins-Keeran et al., 2001; air: Billard, 1981; Billard and Legendre, 1982; Bencic et al., 2000; Jenkins-Keeran et al., 2001; nitrogen: Bencic et al., 2000; Jenkins-Keeran et al., 2001). The quality of the preserved sperm can be evaluated by sperm motility rate, motility duration, and by its fertilising capacity (Rana, 1995).

The Characiformes species used in this study were medium- to large-size fishes of great relevance to commercial fishing and sports. For this reason, they are widely used in fry mass production destined to commercial farms and restocking programs. Brycon lundi Reinhardt have had its stocks greatly reduced and its natural populations are currently endangered (Lins et al., 1997). The objective of this study was to determine the effectiveness of cold storage of sperm from Neotropical species by assessing sperm motility and its fertilising capacity.

\section{MATERIAL AND METHODS}

All storage experiments were conducted using small $\left(\begin{array}{llllll}23 & \mathrm{x} & 18 & \mathrm{x} & 14 & \mathrm{~cm}\end{array}\right)$ styrofoam boxes containing a $3-\mathrm{cm}$ layer of ice cubes or a frozen thermogel bag. To help maintain the temperature and facilitate transport, these boxes were placed inside a larger $(80$ x 50 x $58 \mathrm{~cm})$ styrofoam box.

\section{Storage temperature determination}

In three preliminary assays, the storage temperatures inside the small styrofoam boxes containing ice cubes or a frozen thermogel bag were hourly recorded with the help of a thermopar thermometer. The assays with ice cubes lasted for $6 \mathrm{~h}$; at this time, the ice was melting. The assays with thermogel bags extended for $12 \mathrm{~h}$.

\section{Fish and sperm collection}

The following species were used (with the respective number of individuals used and their weight and total length, in parenthesis): Brycon lundii Reinhardt (4; 577.5 $\pm 121.2 \mathrm{~g} ; 37.4 \pm 2.4 \mathrm{~cm})$, Piaractus mesopotamicus (Holmberg) (6; $2971.7 \pm 987.3$ g; $51.0 \pm 4.6 \mathrm{~cm})$, Leporinus elongatus Valenciennes $(4 ; \quad 378.3 \pm 110.0 \mathrm{~g}$; $34.1 \pm 2.0 \mathrm{~cm}$ ), Leporinus friderici (Bloch) (5;
$472.0 \pm 150.0 \mathrm{~g} ; 28.0 \pm 9.5 \mathrm{~cm})$, Prochilodus lineatus (Valenciennes) $(6 ; 1470.0 \pm 706.5 \mathrm{~g} ; 47.9 \pm 0.6 \mathrm{~cm})$ and Prochilodus marggravii (Walbaum) $(6 ; 414.2 \pm 162.6 \mathrm{~g} ; 32.8 \pm 3.6 \mathrm{~cm})$. The donors, originated from hatchery station, were previously maintained in earthen ponds where they received commercial feed daily, containing a minimum of $22 \%$ crude protein. From November, 1999 to January, 2000, the fish were ready to yield sperm. At this time, the sperm oozed from the genital papilla under slight manual pressure. The coelomic wall of the fish was massaged gently and the extruded sperm collected in 12-mL plastic capped tubes. In collecting the sperm, great care was taken to prevent contamination with urine, faeces, blood and/or water. Test for contamination was performed by observing a small drop of each fresh sperm sample on a glass slide under the light microscope at 400x. Samples showing no sperm motility were used in the experiments.

\section{Sperm storage}

Sperm from each individual was divided into two aliquots of 0.5 to $2 \mathrm{~mL}$ each. One of the aliquots was placed in a $10 \times 20-\mathrm{cm}$ plastic bag inflated with oxygen (sperm from $P$. mesopotamicus, $L$. elongatus, $L$. friderici, $P$. lineatus and $P$. marggravii) or air ( $B$. lundii) and the other one was kept in the original capped tube. The ratio sperm: air or oxygen (v:v, mL) was 1:110-440. The aliquots were stored in the small styrofoam boxes containing either ice cubes or a frozen thermogel bag. Oxygen or air and ice cubes were renewed at intervals of approximately $6 \mathrm{~h}$, whereas the frozen thermogel bags were renewed at 12-h intervals.

\section{Sperm motility activation}

Before the storage tests, $\mathrm{NaCl}$ solutions of different osmolalities were tested for sperm motility activation. The sperm samples were prediluted at a ratio of $1: 100$ with $\mathrm{NaCl} 200 \mathrm{mM}$ (previously established as non-activator of sperm motility). This mixture was again diluted (final dilution ratio $=1: 1000$ ) with $\mathrm{NaCl}$ solutions at various concentrations $(150,100,75,50,25 \mathrm{mM})$, and immediately analysed. Motility rates were obtained under a light microscope, using $400 \mathrm{x}$ magnification. The two-stage dilution of the sperm was carried out as recommended by Billard and Cosson (1992) for adequate motility evaluation. 
The $\mathrm{NaCl}$ concentration at which the highest sperm motility rate occurred, i.e. $50 \mathrm{mM}$, was used for activation of the spermatozoa during the storage experiments. The sperm motility analyses were performed at intervals of $\sim 5-9 \mathrm{~h}$ and continued until the rate of sperm motility reached $\sim 30 \%$.

\section{Fertilisation with stored sperm}

A fertilisation test was made with stored sperm from Prochilodus marggravii of a hatchery station following its routine protocol (Sato et al. 1996). Sperm from two fishes was pooled $(1.5 \mathrm{~mL})$, kept cool for $8 \mathrm{~h}$ in a plastic tube on a frozen thermogel bag, as described before, and used for the fertilisation of $240 \mathrm{~g}$ of eggs obtained by artificially induced spawning. Approximately one $\mathrm{h}$ prior to fertilisation, sperm motility rate was estimated (\%). Eggs and sperm were placed in a plastic bowl and gently mixed together, with water from the incubators being added. After being washed and hydrated, the eggs were divided into two portions and each portion was transferred to a funnel-type, 60-L capacity plastic incubator. Egg samples from both incubators were collected $5 \mathrm{~h}$ after fertilisation and immediately fixed in $4 \%$ formalin buffered solution. The percentage of viable eggs, as identified under a stereomicroscope, was then determined as a measure of the fertilising success. Fertilisation rates obtained with fresh sperm in the routine work of the hatchery station was used as control. Historical hatchery station of $P$. marggravii fertility rate was $68.8 \pm 18.7$ (Sato et al., 1996).

\section{Statistical analyses}

The sperm motility rates of sperm stored in both containers were compared using the MannWhitney U. test. Kruskal-Wallis test was applied to detect any differences in sperm motility rate at the different time intervals. Median differences were considered to be significant at $P<0.05$ (Statistica for Windows, Tulsa, OK, 1996).

\section{RESULTS}

\section{Storage temperatures}

The assays made with ice cubes or frozen thermogel bag showed temperatures averaging from 1.7 to $4.9^{\circ} \mathrm{C}$ over the zero - $12 \mathrm{~h}$ interval. During these assays, room temperature was 21.8 to $24^{\circ} \mathrm{C}$.

\section{Motility rate of stored sperm}

The rates of sperm motility gradually declined over the course of the experiments, with variations occurring between species and individuals of the same species (Fig. 1). Such a decline in sperm motility rates was significant for all species $(P<0.05)$. However, there were no significant differences in sperm motility rates between samples from either storage environment - plastic bag and plastic tube $(P>0.05)$ - except for $P$. marggravii at $6 \mathrm{~h}$. Considering a sperm motility rate of $30 \%$, which could still have practical applications, this value was reached at $7 \mathrm{~h}$ in L. friderici and at $20 \mathrm{~h}$ in P. lineatus (Fig. 1); representing, respectively, the shortest and longest storage duration.

\section{Fertilisation}

The percentages of Prochilodus marggravii eggs fertilised with $8 \mathrm{~h}$ stored sperm were 88 and $90 \%$, respectively, for the two incubators.

\section{DISCUSSION}

Sperm immotility in all species of this study, when incubated in $\mathrm{NaCl} 200 \mathrm{mM}$, suggested that the osmolality of their seminal fluid probably did not differ from that of teleosts in general (Morisawa and Suzuki, 1980). Sperm from all species studied was induced to motility by a reduction in the osmotic pressure of the diluent as demonstrated in other species (Morisawa and Suzuki, 1980; Billard and Cosson, 1992; Cosson et al., 1999). Considering that the dilution rate was a determining factor in the characterisation of sperm motility, a relatively high rate of dilution was used to produce simultaneous activation of almost all spermatozoa, following the recommendation of Billard and Cosson (1992). The method described in this work allowed sperm storage in cooled plastic bags and capped tubes for at least $7 \mathrm{~h}$, at temperatures averaging from $1.7-4.9^{\circ} \mathrm{C}$. With frozen thermogel bags, temperatures up to $4.9^{\circ} \mathrm{C}$ were maintained during $12 \mathrm{~h}$ of storage, which made them more advantageous than ice cubes. Sperm motility rates gradually declined over the period of storage, with marked individual variation. No attempt was made to determine the probable causes of such variations, yet the following could explain them: i) use of a subjective scale for motility evaluation, which might have led to measurement errors; ii) 
difficulty in adequately evaluate contamination of the samples with urine or faeces (Saad and Billard, 1995; Legendre et al., 1996), undetected a priori; iii) differences in $\mathrm{pH}$ levels - not evaluated in our study - between the seminal plasma and the diluting solution (Cosson et al., 1999); and iv) thermal shock (Billard et al., 1993).
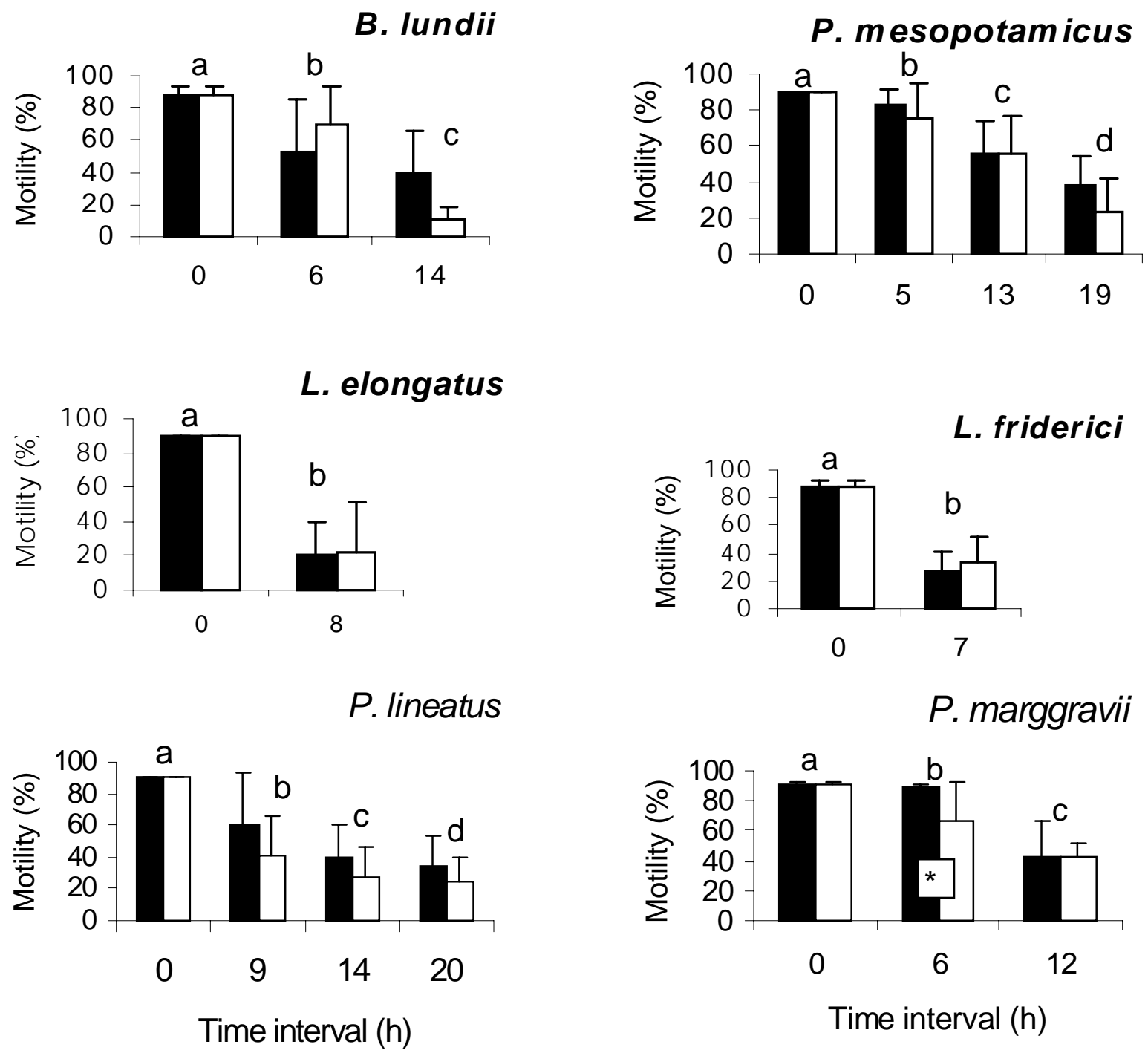

Figure 1 - Sperm motility (\%) at different time intervals (h) using $\mathrm{NaCl} 50 \mathrm{mM}$ as activating solution; dark column $(\mathbf{\square})$ : sperm stored in plastic bag; blank column $(\square)$ : sperm stored in plastic tube; different letters above columns indicate significant differences $(P<0.05)$ between time intervals in each storage recipient; $*=$ significant difference between storage recipients $(P<0.05)$.

The environments in which sperm is stored are critical to successful preservation, as they must be capable of ensuring that spermatozoa remain viable outside the genital tract. Plastic bags gassed with air or oxygen and plastic tubes stoppered to prevent drying (Billard et al., 1993) both proved useful for the preservation of sperm from our species. The presence of oxygen is considered to be important for the sperm preservation process (Billard, 1981; McNiven et al., 1993; Bencic et al., 2000; Jenkins-Keeran et al., 2001). Although the ratio of sperm:oxygen or air was as recommended by Stoss and Refstie (1983), the addition of oxygen or air did not result in significant 
improvement of sperm viability of our fish, except in the case of P. marggravii. Its sperm, kept for 6 $\mathrm{h}$ in plastic bags gassed with oxygen, exhibited significantly higher sperm motility when compared with the sperm stored in the original capped tubes (Fig. 1).

Although sperm may be preserved in diluted form (Legendre et al., 1996), in this study we used it undiluted, fresh and integral. According to Cosson et al. (1999), sperm for preservation should show initial sperm motility rates of more than $90 \%$. All sperm used in this study had an initial motility rate of at least $80 \%$ (see Fig. 1). Duration of sperm viability, considering the minimal practical rate of $30 \%$, varied from 7 to $20 \mathrm{~h}$ in the different species used in this work. Sperm from L. friderici and $L$. elongatus, both of the Anostomidae family, had the shortest duration of motility, i.e. 7-8 h, whereas that from $P$. mesopotamicus and $P$. lineatus remained motile until 19-20 h, when a motility rate of $\sim 40 \%$ was reached. The $30-\mathrm{h}$ period of survival reported by Ferraz de Lima et al. (1989) for P. mesopotamicus sperm cannot be compared with the data obtained in this study, since sperm motility rate at the end of the survival period was not mentioned by those authors. Sperm from fishes of temperate regions can remain viable for much longer periods - days or weeks - (Billard, 1981; Billard and Legendre, 1982; Hara et al., 1982; Stoss and Refstie, 1983; Ciereszko and Dabrowski, 1994; Dilauro et al., 1994; Bencic et al., 2000; Jenkins-Keeran et al., 2001), as compared to the results reported here for Neotropical fishes.

The high percentages of $P$. marggravii eggs that were fertilised with $8 \mathrm{~h}$ stored sperm, comparable to those obtained with fresh sperm under routine hatchery conditions (Sato et al., 1996), confirmed the applicability of the cooling preservation technique described herein. Thus, sperm of the species studied here could be preserved for up to $20 \mathrm{~h}$ in some cases, maintaining its fertilising capacity, when stored in plastic bags, with or without oxygen addition, or in capped tubes, at temperatures between 1.7 to $4.9^{\circ} \mathrm{C}$.

\section{ACKNOWLEDGEMENTS}

The authors thank the following Brazilian fish hatcheries: Mangueira Hatchery, Buritizeiro, MG; Furnas Hatchery Station, FURNAS, Alpinópolis, MG; Três Marias Hatchery Station, CODEVASF,
Três Marias, MG, and Volta Grande Hatchery, CEMIG, Conceição das Alagoas, MG; and CAPES for the fellowship granted to S.M. Thanks are also due to R. Young for the comments and criticisms in the manuscript.

\section{RESUMO}

O sêmen das seguintes espécies de Characiformes neotropicais foi testado para armazenamento em ambiente resfriado: Brycon lundii, Piaractus mesopotamicus, Leporinus elongatus, Leporinus friderici, Prochilodus lineatus e Prochilodus marggravii. Amostras de sêmen, obtidas por massagem da parede celômica, foram armazenadas em saco plástico com ar ou oxigênio ou em tubo plástico com ar, e mantidas resfriadas entre $1,7-4,9^{\circ} \mathrm{C}$. A taxa de motilidade espermática foi estimada usando-se $\mathrm{NaCl} 50 \mathrm{mM}$ como solução ativadora. $\mathrm{O}$ sêmen com menor duração de viabilidade $(7 \mathrm{~h})$ foi o de $L$. friderici, quando a taxa de motilidade espermática alcançou $~ 30 \%$, enquanto que o de maior duração $(20 \mathrm{~h})$ foi o de $P$. lineatus. A fertilização de ovócitos utilizando sêmen refrigerado por $8 \mathrm{~h}$ de Prochilodus marggravii produziu $88-90 \%$ de embriões viáveis. $\mathrm{O}$ método de armazenamento desenvolvido neste trabalho tem aplicações práticas, especialmente no manejo reprodutivo de peixes em estações de piscicultura.

\section{REFERENCES}

Barret, I. (1951), Fertility of salmonid eggs and sperm after storage. J. Fish Res. Bd. Can., 8, 125-133.

Bencic, D. C.; Krisfalusi, M.; Cloud, J. G. and Ingermann, R. L. (2000), Short-term storage of salmonid sperm in air versus oxygen. North Am .J. Aquaculture, 62, 19-25.

Billard, R.; Cosson, J. and Crim, L. W. (1993), Motility of fresh and aged halibut sperm. Aquat. Living Resour., 6, 67-75.

Billard, R. and Cosson M. P. (1992), Some problems related to the assessment of sperm motility in freshwater fish. J. Exp. Zoo., 261, 122-131.

Billard, R. and Legendre, M. (1982), Conservation a court terme des gamètes de truite arc-en-ciel en condition in vitro sous atmosphère d'oxygene. Bull. Fr. Piscic., 284, 162-167.

Billard, R. (1981), Short-term preservation of sperm under oxygen atmosphere in rainbow trout (Salmo gairdneri). Aquaculture, 23, 287-293. 
Chereguini, O.; Cal, R. M.; Dreanno, C.; Orgier De Baulny, B.; Suquet, M. and Maisse, G. (1997), Shortterm storage and cryopreservation of turbot (Scophthalmus maximus) sperm. Aquat. Living Resour., 10, 1-5.

Ciereszko, A. and Dabrowski, K. (1994), Relationship between biochemical constituents of fish semen and fertility: the effect of short-term storage. Fish Physiol. Bioch., 12, 357-367.

Cosson, J.; Billard, R.; Cibert, C.; Dréanno, C. and Suquet, M. (1999), Ionic factors regulating the motility of fish sperm. In: Gagnon, C. (Ed.). The male gamete: from basic science to clinical applications. Vienna : Cache River Press. pp. 162-186.

Dilauro, M. N.; Krise, W. F.; Hendrix, M. A. and Baker, S. E. (1994), Short-term cold storage of Atlantic sturgeon sperm. Prog. Fish-Cult., 56, 143-144.

Ferraz de Lima, J. A.; Castagnolli, N. and Figueiredo, G. M. (1989), Reprodução, larvicultura e genética.In: Hernandez, A. (Ed.). Cultivo de Colossoma. Colômbia : Red Regional de Entidades y Centros de Acuicultura de America Latina. pp. 315-332.

Hara, S.; Canto Jr.; J. T. and Almendras, J. M. E. (1982), A comparative study of various extenders for milkfish, Chanos chanos (Forsskål), sperm preservation. Aquaculture, 28, 339-346.

Henderson, N. E. and Dewar, J. E. (1959), Short-term storage of brook trout milt. Prog. Fish-Cult, 21, 169-171.

Jenkins-Keeran, K.; Schreuders, P.; Edwards, K. and Woods III, L. C. (2001), The effects of oxygen on the short-term storage of striped bass semen. North Am. J. Aquaculture, 63, 238-241.

Kavamoto, E. T.; Fogli da Silveira, W.; Rigolino, M. G.; Tabata, Y. A. and Campos, B. E. S. (1987), Produção espermática e teste de fertilização do sêmen de truta arco-íris, Salmo irideus Gibbons no primeiro ciclo reprodutivo. B. Inst. Pesca, 14, 51-62.

Lahnsteiner, F. and Patzner, R. A. (1998), Sperm motility of the marine teleosts Boops boops, Diplodus sargus, Mullus barbatus and Trachurus mediterraneus. J. Fish Biol., 52, 726-742.

Legendre, M.; Linhart, O. and Billard, R. (1996), Spawning and management of gametes, fertilized eggs and embryos in Siluroidei. Aquat Living Resou., 9, 59-80.

Lins, L. V.; Machado, A. B. M.; Costa, C. M. R. and Herrmann, G. (1997), Roteiro metodológico para elaboração de listas de espécies ameaçadas de extinção: contendo a lista oficial da fauna ameaçada de Minas Gerais. Belo Horizonte : Fundação Biodiversitas. 55 pp.

Mcniven, M. A.; Gallant, R. K. and Richardson, G. F. (1993), Fresh storage of rainbow trout (Oncorhynchus mykiss) semen using a non-aqueous medium. Aquaculture, 109, 71-82.
Morisawa, M. and Susuki, K. (1980), Osmolality and potassium ion: their roles in initiation of sperm motility in teleosts. Science, 210, 1145-1147.

Rana, K. (1995), Preservation of gametes. In: Bromage, N. R. and Roberts, R. B. (Eds.). Broodstock management and egg and larval quality. Oxford : Blackwell. pp. 53-75.

Saad, A.and Billard, R. (1995), Production et gestion des spermatozoïdes chez le poisson-chat européen Silurus glanis. Aquat. Living Resour., 8, 323-328.

Sato, Y.; Cardoso, E. L.; Godinho, A. L. and Godinho, H. P. (1996), Hypophysation parameters of the fish Prochilodus marggravii obtained in routine hatchery station conditions. Rev. Brasil. Biol., 56, 59-64.

Stoss, J. and Refstie, T. (1983), Short-term storage and cryopreservation of milt from Atlantic salmon and sea trout. Aquaculture, 30, 229-236.

Wayman, W. R.; Tiersch, T. R. and Thomas, R. G. (1998), Refrigerated storage and cryopreservation of sperm of red drum, Sciaenops ocellatus L. Aquaculture Research, 29, 267-273.

Received: February 21, 2003; Revised: August 06, 2003; Accepted: February 04, 2004. 